\title{
HEALTH EDUCATION PROGRAM: A PHARMACEUTICAL PERSPECTIVE
}

\author{
CAVALHEIRO, Amanda Henriques ${ }^{1}$
} GOBBI, Maria do Carmo Marques ${ }^{2}$

SUMMARY: The concern about therapies and procedures to improve patients' quality of life and adherence to the treatment has led some pharmaceutical companies to invest in educational programs. Since in the literature there are still few studies related to preventive and therapeutic education (mainly private ones), it is imperative that the overall care of this individual be performed. Studies have shown that the quality of life of these patients can be modified through their attitude, responses and action, of the professionals involved, caregivers and health policies, so that they have the possibility to develop abilities, skills and choices. The education programs are developed based on methodologies, techniques of approach and the concept of humanized care, with a simple, clear, objective and accessible language. This way, pharmaceutical care as health instructors enables the patient to the correct use of the prescribed medicines, which may reduce their adverse effects and increase their effectiveness, creating adherence to the treatment and better quality of life.

Keywords: Health instructor. Chronic and rare diseases. Health education programs.

RESUMO: A preocupação com terapias e procedimentos eficazes para melhorar a qualidade de vida dos pacientes e a adesão ao tratamento levou algumas empresas farmacêuticas a investir em programas educacionais. Como na literatura ainda existem poucos estudos relacionados à educação preventiva e terapêutica (principalmente os privados), é imprescindível que o cuidado global desse indivíduo seja realizado. Estudos têm demonstrado que a qualidade de vida desses pacientes pode ser modificada por meio de suas atitudes, respostas e ações, dos profissionais envolvidos, cuidadores e políticas de saúde, para que eles tenham a possibilidade de desenvolver habilidades e escolhas. Os programas de educação são desenvolvidos com base em metodologias, técnicas de abordagem e no conceito de cuidado humanizado, com uma linguagem simples, clara, objetiva e acessível. Dessa forma, a assistência farmacêutica, como instrutores de saúde, possibilita ao paciente o uso correto dos medicamentos prescritos, o que pode reduzir seus efeitos adversos e aumentar sua eficácia, gerando aderência ao tratamento e melhor qualidade de vida.

Palavras-chave: Instrutor de saúde. Doenças crônicas e raras. Programas de educação em saúde.

\section{INTRODUCTION}

Health is a right of all citizens, guaranteed by care policies, besides the access to health services (BRASIL, 1988; SPADA, 2017). However, the government efforts are not enough to solve all the health problems of the society, showing inefficiency and non-resoluteness (CASTRO et al., 2013).The numerous data records associated to error, adverse events, low adherence to treatment, low self-confidence of the patients and none self-managing corroborate this (SPADA, 2017).

This inefficient health system has been changed especially in University Hospitals, where health professionals promote the education of patients and their families, guiding them to participate more effectively in care and to make informed decisions (MEIRELLES et al., 2015; FIGUEIREDO; KROTH; LOPES, 2006).

\footnotetext{
${ }^{1}$ Professor of Pharmacy Thecnician at SENAC/SP, Brazil

${ }^{2}$ Professor at Barão de Mauá, CUBM, Brazil
} 
The patient's health education should be differentiated from counseling during a normal medical visit. Adults benefit from education programs with cognitive-behavioral techniques (FIGUEIREDO, KROTH; LOPES, 2006). For a diabetic, for example, simulation of insulin delivery techniques, carbohydrate counting in practice, capillary blood glucose control before and after meals should be applied during a domiciliary visit (GRILLO et al., 2013). Other methods include hypothetical case study, patient experience management, and support telephone calls (data not published yet). Another point to consider is the viability of the method of education for the institutions and professionals involved.

The benefits of education are reflected in many aspects in patients. One is the improvement of the symptoms or in laboratory results (GRILLO et al., 2013). On the emotional side, knowledge about the potential implications and consequences of the disease and its treatment serves to reduce anxiety and facilitate lifestyle adjustments (MARTINS; CESARINO, 2004).

Educational programs are still able to reduce health care costs by reducing the need for medications, the number of doctor visits and the use of hospital services (GRILLO et al., 2013). Besides, the increase of patients' knowledge about their disease improve adherence to treatment and promote the rational use of medicines.

\section{METHODOLOGIES}

This is a bibliographical research, of qualitative character, developed from the scientific studies carried out on the chosen theme. A bibliographic survey was carried out through an electronic consultation using the Pubmed databases, as well as an extensive consultation in books, Laws of the Ministry of Health, Federal Laws and recommendations of ANVISA and the Federal Council of Pharmacy. Surveys will include manuscripts in English and Portuguese, published in databases by May 2018.

\section{HEALTH INSTRUCTORS - PHARMACISTS}

After the Industrial Revolution, pharmaceutical activities had a mercantilist approach, gradually replaced by the production of drugs in scale by the pharmaceutical industry. The pharmaceutical profession experienced the loss of its identity and the pharmacies became a commercial establishment, turned to profit. The pharmacists lost their autonomy in the performance of activities, distancing from the role of health agent (SPADA, 2017).

Besides all the mercantilist view, pharmacies are important places to seek care and possible door entry for patients in the health system. Pharmacists are the most available health professionals for the population (DA SILVA; NAVES; VIDAL, 2008). In this context, pharmacy services are as relevant to patient care as services provided by other health professionals. This provides community pharmacists with the opportunity to provide patient counseling, interact and discuss their needs, providing information about medications and the care of diseases, including the search for other professionals (DA SILVA; NAVES; VIDAL, 2008).

In chronic diseases, such as arthritis, diabetes or rare diseases, the patient is the main actor in his treatment, there are many tasks that must be performed, such as using medications in a proper way, interpret and report symptoms correctly and participate in decisions about treatment (EIZERIK; COSTA; MANFROI, 2008). In addition, in this type of patient, cure is unlikely and prognosis uncertain. 
Studies with hypertensive patients reported that a good orientation to patients on the side effects of medications results in better adherence to antihypertensive treatment (LIP; BEEVERS, 1997). Another one, studying lipid-lowering medication, analyzed the educational intervention made by pharmacists,

including since in the participation in the selection of the medication until the contact with the patient. The intervention included educating patients about the disease, medication, diet, lifestyle, pharma cotherapeutic and discussion of cases with physicians. Experiments have suggested that pharmaceutical approach helps patients to adhere to treatment, modify their risk factors and achieve their therapeutic goals (FURMAGA, 1993).

Patients with heart failure who received home-based educational interventions presented lower rates of demand for emergency services, lower health costs, as well as a less deaths outside the hospital and improvement in quality of life. (AGUADO et al., 2010)

However, there is still an incipient demand for pharmacists to be health instructors contracted by pharmaceutical companies to carry out this educational monitoring (data not published yet).

\section{COUNSELING}

Counseling is an individualized process of active and patient-centered listening. It is the ability to establish a relationship of trust between pharmacist and patient, seeking to rescue the internal resources of the individual. Therefore, the patient is an active character, recognizing himself as the subject of his own health and transformation (DA SILVA; NAVES; VIDAL, 2008).

The main aim is to strengthen the patient's abilities in conducting their treatment and in solving problems to improve or maintain their health and quality of life. During the counseling activity, health professionals should recognize each patient as a unique human being with stories of life, health problems, social context, believes, routine of life and specific needs (DA SILVA; NAVES; VIDAL, 2008).

There are no guide to establish effective pharmaceutical advice, but according to the profile of each patient, different items can be approached with greater or lesser emphasis. The basic content should cover the discussion about the diseases presented, their treatment and healthy habits of life (GRILLO et al., 2013). During the process, it is important to make the patient think about their health and their illnesses, in order to active their participation in the therapeutic process.

Regarding pharmacological treatment, during counseling the patient should receive objective information such as dose, duration of treatment, form of administration, use of devices, possible adverse reactions, among others. It is important to explain specific information such as the reason for the use, the benefits of its use and the risks of non-use (SIMÕES; NATOUR, 2002).

\section{EDUCATION}

Teaching is not transferring knowledge (FREIRE, 2003). The process of education can be described by the assessment of prior knowledge, cognition, attitudes, motivation and mistakes made by patients, aiming to raise awareness about health problems (LEITE; ZANIM; GRANZZOTO; HEUPA; LAMOUNIER, 2008; STRÖMBERG, 2002; EIZERIK; COSTA; MANFROI, 2008).

Patient education involves identifying what to teach, considering potential barriers to learning (MARTINS; CESARINO, 2004; VASCONCELOS, 1999). The education plan used in most studies includes information on the disease and its treatment, from prescription to non-pharmacological measures, 
facilitating the understanding of the importance of adherence to treatment and providing positive therapeutic results (GRILLO et al., 2013).

Considering that learning arises from a sharing of information, the technologies of information and communication, widely exploited these days, collaborate with the educational process through the

interaction that they provide and possibilities of personalization of contents (ALVAREZ; DAL SASSO, 2011). There is a wide range of tested educational interventions but not a universal model that can be standardized and recognized as effective for all individuals.

Every human being has his own knowledge, which results from his experience, and respecting this knowledge is essential for learning. From this perspective, the educational process is fundamentally based on listening (SPADA, 2017). One way to educate is, therefore, to build a trusted relationship of trust in a mutual process of knowledge, giving the patient the opportunity to speak. Only in the sincere involvement, the educational process happens (GAZZINELLI; REIS; MARQUES, 2003).

Patient education is any set of educational activities designed to improve patients' behavior in the face of illness and thereby improve health status with long-term results. It is not a treatment alone, it is an adjunct to standard treatment by persuading patients to adhere better or adopt attitudes that are beneficial with regard to the disease (MARTINS; CEZARINO, 2004).

\section{HOW HEALTH EDUCATION PROGRAMS WORK}

Generally, at the beginning of the chronical or rare disease, the patient is not prepared to receive any kind of health instructor. It happens because normally is a period of regret and accepting phase. After this phase, the health instruction starts.(MEIRELLES et al., 2015).

Telephone monitoring is no longer a new resource for care, since most of the services identified use this means for health education, interventions and the perspective of continuity of care. However, it is still used by companies as a means of communication. Health instructor contacts the patients and visit them in their own homes, to create a good environment to education (data not published yet).

The program can be in individual format or in group. Normally, the most used is in group, because is the least expensive. However, pharmaceutical industries are trying to individualize the health instruction to personalize the care (data not published yet).

Programs should be consistent with feasibility, scope, access, cost-benefit and proposed goals and should be adapted according to the health system. The patient should be aware of what their illness and its consequences are, as they may better adhere to treatment and lifestyle changes (SIMÕES;NATOUR, 2002). Besides, planning the content of education, with the participation of the patient, to define individual goals and choose the best interventions to reach them, how education will be dispensed and a careful evaluation of the education process instituted is essential to a good approach (STRÖMBERG, 2005).

The home visit is a category that prioritizes the individual's reality and educational actions. It is a fundamental intervention instrument in family health and in the continuity of any form of care, being programmed and used in order to subsidize interventions or the planning of actions (SIMÕES;NATOUR, 2002).

Besides, the health instructors take notes about the patient and fill forms to have everything notified and organized. In circumstances of pharmacovigilance, the health instructor is responsible to notify the company to communicate the regulator organ. As said, at the moment of instruction, the professional needs to verify the motivation and adherence of the patient, observing what is necessary to 
explain or practice (GOMES, COUTINHO, MIYAMOTO, 2014). Some companies use questionnaires to evaluate patient adherence (data not published yet).

The change in the lifestyle, the maintenance of the care, the resolution of problems and selfconfidence are characteristics of success of the educational process (LEITE et al., 2008).

\section{CONCLUSION}

The main objective of the education program is to train patients to be self-confidents, take decisions regarding their treatment and be capable of identify symptoms and situations that must be analyzed by a health professional.

In other words, the educational process increases patient autonomy and increase the adherence in the treatment. For this process to be successful, the patient must actively participate in the learning process and the knowledge must be evaluated with forms periodically or after the domiciliary visit. Another important aspect is to define individual goals and to establish a continuous relationship with the patient.

It is through the communication established with the patient that one can understand it in its whole (FIGUEIREDO, KROTH, LOPES, 2006). This is the only way to identify the problems the patient feels, based on the meaning it is attributed to the facts that occur, and try to help or maintain the health. From the moment the patient feels respected and becomes aware of the importance as an agent responsible for his own health, he begins to take better care of himself, which has a direct positive effect on his health.

Pharmacists can perform this kind of job, and nowadays pharmaceutical industries are seeking for this kind of professional. Pharmaceutical care enables the patient to correctly use the prescribed medicines, which may reduce their adverse effects and increase their effectiveness.

\section{REFERENCES}

AGUADO, O.et al. Long-term implications of a single home-based educational intervention in patients with heart failure. Heart \& Lung: The Journal of Acute and Critical Care, v.39, n.6, p. S14-S22, 2010.

ALVAREZ, A.G.; DAL SASSO, G.T. M. Aplicação de objeto virtual para avaliação simulada da dor aguda em estudantes de enfermagem. Rev. Latino-Am. Enfermagem, v.19, n.2, 2011.

BRASIL. Constituição (1988). Constituição da República Federativa do Brasil. Brasília: Senado; 1988.

CASTRO, S.F.F. et al. Acreditação no contexto de um hospital público: achados da avaliação externa diagnóstica. RevAcred., v.3, n.6, p.1-13, 2013.

DA SILVA, E.V.; NAVES, J.O.S.; VIDAL, J. O papel do farmacêutico comunitário no aconselhamento ao paciente. Boletim Farmacoterapêutica, v.4, p.1-5, 2008.

EIZERIK, D.P.; COSTA, A.F.; MANFROI, W.C. Educação de pacientes em dislipidemia: revisão sistemática. Rev. Bras. Farm., v.89, n.3, p.207-210, 2008.

FIGUEIREDO, A.E.; KROTH, L.V.; LOPES, M.H.I. Peritoneal dialysis: patient education based on the self-care model. Scientia Medica, v.15, n.3, 2006.

FURMAGA, E.M. Pharmacist management of a hyperlipidemia clinic. Am. J. Hosp. Pharm., v.50, n.1, p.91-95, 1993.

GAZZINELLI, M.F., REIS, D.C., MARQUES, R.C. Educação em saúde: teoria, método e imaginação. Belo Horizonte: Ed UFMG, 2006. 166 p. 
GOMES, C.M.S.; COUTINHO, G.C.; MIYAMOTO, S.T. Efeitos do programa de educação em pacientes com artrite reumatoide do Serviço de Reumatologia do Hospital Universitário Cassiano Antônio de Moraes (HUCAM)-projeto piloto. Rev. Terap Ocup da Univ São Paulo., v.24, n.3, p.250-258, 2014.

GRILLO, M.D.F.F.et al. Effect of different types of self-management education in patients with diabetes. Revista da Associação Médica Brasileira, v.59, n.4, p.400-405, 2013.

LEITE, S.A.O.et al. Pontos básicos de um programa de educação ao paciente com diabetes melito tipo 1. Arq Bras EndocrinolMetab., v.52, n.2, p.233-242, 2008

LIP, G.Y.; BEEVERS, D.G. Doctors, nurses, pharmacists and patients - the Rational Evaluation and Choice in Hypertension (REACH) survey of hypertension care delivery. Blood Press Suppl., v.1, p.6-10, 1997.

MARTINS, M.R.I.; CESARINO, C.B. Atualização sobre programas de educação e reabilitação para pacientes renais crônicos submetidos à hemodiálise. J BrasNefrol.,, v.26, n.1, p.45-50, 2004.

MEIRELLES, R.N.et al. Implantação de um Programa de Educação do Paciente em um Hospital Público. Revista Baiana de Saúde Pública., v.39, n.3, p.668, 2015.

SIMÕES, M.F.J.; NATOUR, J. Educação do paciente em Reumatologia. Sinopse de reumatologia.v.4, n.2, 2002.

SPADA, K. A função educativa do farmacêutico no sistema único de saúde. Disponível em www.pucpr.br/eventos/educere/educere2007/anais Evento/ arquivos/CI-180-01.pdf. Acessoemjulho de 2017.

STRÖMBERG A. The crucial role of patient education in heart failure. Eur. J. Heart Fail,v.7, p.363-369, 2005.

VASCONCELOS, E.M. Educação popular e a atenção à saúde da família. São Paulo: Hucitec, 1999. 